\title{
Mechanisms of international influence on domestic elite sport policy $^{1}$
}

\section{Barrie Houlihan}

\section{Explaining policy stability and change}

In the mid-1990s Cerny (1995) argued that domestic policy making was increasingly constrained by international economic, political and cultural forces, and Coleman and Perl concluded that globalisation had 'destabilise[d] traditional divisions of labour between sub-national, national, regional and international authorities' (1999, p. 692). Despite the hyperbole that surrounds much of the debate over the nature and the significance of globalisation it remains a central explanatory variable in recent policy analysis. These arguments resonate powerfully with contemporary elite sport which has a well-established infrastructure of global sports institutions focused on event organising (for example, the International Olympic Committee and the Commonwealth Games Federation) or, as in the case of international federations, focused on both event organising and governance. More recently, these institutions have been joined not only by a powerful set of global sport media businesses which increasingly treat the world as a single market for

\footnotetext{
${ }^{1}$ The author would like to thank the three anonymous referees for their helpful comments on the earlier draft of this paper.
} 
their range of sports events and competitions, but also by a growing number of international governmental organisations with either a primary (e.g. International Intergovernmental Consultative Group on Anti-Doping in Sport, IICGAD) or secondary (e.g. Council of Europe, the European Union and UNESCO) interest in sport. The emergence of this global infrastructure for sport has prompted greater investigation of the impact of international or nondomestic factors on domestic elite sport policy.

In a study of the elite sport development systems in the UK, Australia and Canada Green and Houlihan (2005) concluded that all three countries had, over the previous ten years or so, experienced an increase in government intervention intended to establish and refine elite policy objectives. These objectives were to be achieved largely through the provision of substantial investment of public and lottery funds in dedicated elite-focused facilities, specialist coaching, sports science and sports medicine support. These countries also experienced the reshaping, by domestic federations, of the competition calendar to suit the requirements of elite performance at international competition, especially, the Olympic Games. These conclusions were reinforced by a number of other studies conducted around the same time (Abbott et al. 2002, Digel 2002a, 2002b, Green and Oakley 2001a, 2001b, Oakley and Green 2001, UK Sport 2006). Table 1 provides a summary of their findings and suggests that the characteristics of successful elite systems have many common features which could be grouped under three main headings: contextual, processual and sport specific. Reflecting on the similarity between elite sport systems Oakley and Green argued that the ten characteristics that they identified represented 'common approaches to the 
problem of enhancing elite sport rather than responses to the social, political and economic elements in each country' (2001, p. 91) which indicated 'that there is a growing trend towards a homogeneous model of elite sport development' (2001, p. 91). Oakley and Green's conclusion is broadly endorsed by Digel (2002a, 2002b) and more recently by Houlihan and Green (2008) who found that all countries in their edited study, with the exception of the USA, exhibited many common characteristics and concluded that ' the countries discussed ... provide strong evidence of strategic approaches based increasingly around a homogenous model of elite sport development but with subtle domestic variations' (2008, p. 291). 
Table 1: Factors contributing to elite success

\begin{tabular}{|c|c|c|c|c|}
\hline Factors & Oakley and Green & Digel & $\begin{array}{l}\text { UK Sport (SPLISS } \\
\text { Consortium) }\end{array}$ & Green and Houlihan \\
\hline \multirow[t]{3}{*}{ Contextual } & An excellence culture & $\begin{array}{l}\text { Support, especially } \\
\text { financial, of the state }\end{array}$ & Financial support & Support for 'full-time' athletes \\
\hline & Appropriate funding & $\begin{array}{l}\text { Economic success and } \\
\text { business sponsorship }\end{array}$ & Participation in sport & \\
\hline & & $\begin{array}{l}\text { A media-supported positive } \\
\text { sports culture }\end{array}$ & Scientific research & \\
\hline \multirow[t]{6}{*}{ Processual } & $\begin{array}{l}\text { Clear understanding of the role of } \\
\text { different agencies }\end{array}$ & $\begin{array}{l}\text { Talent development } \\
\text { through the education } \\
\text { system }\end{array}$ & $\begin{array}{l}\text { Talent identification and } \\
\text { development system }\end{array}$ & \\
\hline & Simplicity of administration & $\begin{array}{l}\text { Talent development } \\
\text { through the armed forces }\end{array}$ & $\begin{array}{l}\text { Athletic and post career } \\
\text { support }\end{array}$ & \\
\hline & $\begin{array}{l}\text { Effective system for monitoring } \\
\text { athlete progress }\end{array}$ & & $\begin{array}{l}\text { Integrated approach to } \\
\text { policy development }\end{array}$ & \\
\hline & $\begin{array}{l}\text { Talent identification and targeting } \\
\text { of resources }\end{array}$ & & $\begin{array}{l}\text { Coaching provision and } \\
\text { coach development }\end{array}$ & \\
\hline & $\begin{array}{l}\text { Comprehensive planning system } \\
\text { for each sport }\end{array}$ & & & \\
\hline & Lifestyle support & & & \\
\hline \multirow[t]{3}{*}{ Specific } & $\begin{array}{l}\text { Well structured competitive } \\
\text { programmes }\end{array}$ & $\begin{array}{l}\text { Sports science support } \\
\text { services }\end{array}$ & International competition & $\begin{array}{l}\text { A hierarchy of competition } \\
\text { opportunities centred on } \\
\text { preparation for international } \\
\text { events }\end{array}$ \\
\hline & Well developed specific facilities & & Training facilities & Elite facility development \\
\hline & & & & $\begin{array}{l}\text { The provision of coaching, } \\
\text { sports science and sports } \\
\text { medicine support services }\end{array}$ \\
\hline
\end{tabular}

Sources: Digel (2002a, 2002b), Green and Houlihan (2005), Oakley and Green (2001), UK Sport (2006) 
However, while Houlihan and Green raised the issue of the mechanisms by which this homogeneous model might have been adopted little recent research into sport globalisation takes the mechanisms of international influences on domestic public policy for sport as its central concern. Consequently, the focus of this paper is the interface between national/ domestic sport policy systems and the increasingly prominent and, arguably, extremely influential set of international/non-domestic policy influences. More specifically, the primary aim of this paper is to evaluate the utility, for the analysis of elite sport policy, of the mechanisms of international influence which have been identified in the wider policy analysis literature. This paper is divided into three sections: the first discusses briefly the nature and significance of international influences; the second section examines the character and importance of domestic institutionalised practices - the weight of history - which can either facilitate or constrain policy change; and the final section discusses a series of mechanisms by which the international and the domestic dimensions intersect and by which international influences impact upon domestic elite sport policy.

\section{International influences and domestic policy}

Throughout the 1990s much attention was focused on the impact of globalisation on social processes including those associated with policy stability and change. Unfortunately, the often inflated claims regarding the significance, both political and social, of globalisation prompted a sceptical 
reaction against the paradigmatic status that the concept seemed to be assuming. Unease focused on the utility of the concept, its descriptive accuracy and its explanatory potential (Bauman 1999, Rosenberg 2005, Fitch 1996). Thus, while there is acknowledgement of the significance of globalisation the concept suffers in its application as an explanatory variable from vagueness, and casual and inconsistent usage (Hirst and Thompson 1999, Houlihan 2007). Scholte, (2003) for example, in evaluating the utility of the concept of globalisation, identifies five common uses of the term: internationalisation, liberalisation, universalisation, westernisation/ Americanisation and deterritorialisation with each term giving different weight to economic, political and cultural aspects.

The breadth of interpretation of the concept of globalisation needs to be borne in mind when examining the impact on policy. In the mid 1970s Hechter noted that much of current policy research still assumed that 'the causes of [policy] development were located within units defined by political boundaries, such as sovereign states' (1975, p. 217). By the mid 1990s there was a clear acceptance that an increasing number of policy issues were now embedded in a series of supra-national policy networks and that the problem for the policy analyst was to determine whether actors external to the domestic political system were participants in a national policy process or whether the proper focus should be on the global policy arena to which national actors sought entry and influence (see for example, Andersen and Eliassen 1993).

Deacon, in his analysis of welfare policy (1997), noted that the relative decline in the power of national governments as a result of globally mobile finance capital had altered the traditional approach to welfare policy analysis - 
a view which could be applied with equal force to elite sport policy. According to Deacon supranational policy actors can no longer be ignored especially in relation to the 'globalisation of social policy instruments, policy and provision' (1997, p. 20) which takes three distinct forms - supranational regulation, supranational redistribution and supranational provision. Supranational regulation refers to 'those mechanisms, instruments and policies at the global level that seek to regulate the terms of trade and operation of firms in the interests of social protection and welfare objectives' (1997, p. 2). The European Union provides the best illustration at a regional level, for example in relation to rights at work (as evidenced in relation to sport in the Bosman case) while examples at a global level in sport would include the regulation by international sports federations of the transfer market and eligibility rules for national teams, the role of the World Anti-Doping Agency in shaping national anti-doping policy, and the growing importance of the Court of Arbitration for Sport in settling sports-related disputes.

Examples of sport-related supranational redistribution policies are scarce, but would include the work of Olympic Solidarity and the sport development initiatives of international federations such as the IAAF and FIFA all of which involve some redistribution of income to poorer countries. Supranational provision refers, according to Deacon, 'to the embryonic measures ... whereby people gain an entitlement to a service or are empowered in the field of social citizenship rights by an agency acting at the supranational level' (1997, p. 3). The Court of Arbitration for Sport is beginning to fulfil this role for elite athletes and the UN, through its Convention on the 
Rights of the Child, has the potential to protect the rights of child elite athletes (David 2005).

Within the discussion of the impact of globalisation two more specific trends, commercialisation and governmentalisation, require comment. Commercialisation refers to the rapid expansion of sport-related businesses (most notably sport media) and to the transformation of much sport into successful commodities and brands and has generated considerable research interest (see for example, Slack 2004, Amis and Cornwell 2005, Silk et al 2005). Commercialisation has also had an impact on the ethos and management practices in public services associated with elite sport perhaps most clearly in the UK, Australia and New Zealand, although few developed economies have been immune. In the UK the Labour government's modernisation agenda, which is strongly influenced by commercial management practices, has introduced a series of principles (such as confidence in the market and the development of partnership, participation and stakeholding) and technologies (public service agreements, inspection, 'naming and shaming', and audit) which reinforce the process of commercialisation.

As a distinct aspect of globalisation governmentalisation refers to the development of a state apparatus for the delivery and management of services that were previously the primary or sole responsibility of organisations of civil society. While the former communist countries have a relatively long history of state direction of elite sport a similar pattern, if not quite depth, of involvement emerged in many economically developed noncommunist countries in the 1960s and accelerated from the early 1990s 
(Green \& Houlihan 2008). Although the expansion of government involvement has generally taken place in conjunction with voluntary organisations there has also been a steady accrual of functions by the state with the consequent development of specialist administrative units and agencies at national and sub-national levels, and the allocation of responsibility for policy at ministerial level. By the early part of the twenty-first century elite sport had become so well established within the machinery of government and within the portfolio of government responsibilities that many governments are able to influence significantly the pattern of elite sport opportunities.

Clearly, the extent to which globalisation in general and the particular aspects of commercialisation and governmentalisation are recognised as external to particular domestic policy processes will vary considerably. For a number of countries, especially the more neo-liberal, the international ideological environment will appear far less alien than for countries where the commodification of services is more limited as in the Scandinavian countries and where the capacity of government to expand its role is also limited as in the United States. Consequently, external influences may, in some countries, be reinforcing national administrative patterns, dominant policy paradigms, and deep structural values whereas in others there will be a higher level of conflict at some or all of these levels. The impact of non-domestic influences consequently depends not just on their specific characteristics, but also on the particular pattern of institutional arrangements, both organisational and cultural, at the domestic level. The next section therefore discusses the institutions at the domestic level that mediate international influences. 


\section{Domestic level institutional mediation}

In all countries factors such as the accumulation of previous policy decisions, the organisation of the machinery of government, the history of relations with other countries, the political party structure, and the relationship between the legislature and the executive combine to provide a series of institutionalised variables which mediate the relationship between international influences and the domestic policy system. Although the concept of an institution is defined in a wide variety of ways there are two broad orientations in the literature, one emphasising the significance of institutions as organisational entities and arrangements (agencies, departments, federalism, parliaments etc), and the other, cultural institutionalism, which highlights shared values, norms and beliefs.

Institutions constrain choice through their capacity to shape actors' perception of both problems and acceptable solutions. As such, the emphasis on institutions is a valuable corrective to the tendency of much pluralist theory to treat organisations (government departments, committees of enquiry and local councils, for example) as arenas in which politics takes place rather than as independent or intervening variables in the process. Cultural institutionalism, with its emphasis on values, norms and beliefs, emphasises the social construction of meaning and 'how interest groups, politicians, and administrators decide their policy preferences' (Fischer 2003, p. 29).

Institutions develop at a variety of levels within the socio-political system. While the recursive relationship between agency and structure ensures that 
even institutions at the level of the deep structure (Benson 1982) of society are not immune from change it is at this level (of deeply-rooted social values) and at the levels of core policy paradigm and service specific policy paradigms that the strongest resistance to international influences for change will be encountered unless, of course, there is a correspondence between domestic cultural institutions and the values promoted by the international influences.

The most successful attempt to capture the significance of cultural institutionalism for domestic policy has been by Esping-Andersen (1990) who, in his well-known analysis of welfare states distinguished between three welfare regimes: liberal, conservative and social democratic with the distinction based on the private-public mix, the degree of de-commodification and modes of stratification or solidarities. Esping-Andersen's research stimulated considerable debate (for example, Sairoff 1994, Liebfried 1992) and while there was some refinement of his typology there has been broad support for its underlying premise that forces for change are strongly mediated by deeply rooted cultural predispositions irrespective of whether the source of change is internal or external to the domestic policy system (see Blomqvist 2004, Ozga \& Lingard 2007). It is this observation that has led to the increased concern to move beyond assertions about the strength of international influences for change and the robustness or weaknesses of domestic institutions and which has focused attention on the mechanisms by which factors and pressures external to the domestic policy sector permeate the domestic policy process and influence policy choice. 
However, of equal importance to the empirical specification of international factors and domestic mediating factors is how their interrelationship is theorised and, importantly for this paper, how the particular mechanisms of international influence are theorised. The theorisation of the inter-relationship of non-domestic and domestic factors will be discussed in the conclusion as it is argued that the discussion of the operation of the various mechanisms provides valuable theoretical insight into the long term nature of the relationship. As regards the theorisation of the various mechanisms of international influence one issue which needs to be borne in mind is whether the various mechanisms discussed should be granted a broad equivalence, but not mutual exclusivity, which would allow them to be used in a complementary fashion - a form of theoretical pluralism. The theoretical status of the various mechanisms and their compatibility will also be examined more fully in the conclusion.

\section{Mechanisms of international influence on elite sport policy}

Although it is generally acknowledged that international influences affect an increasing range of domestic policy sectors there is still only a relatively modest body of research which examines how these influences are manifest at the domestic level - the process of influence is significantly underexplored. If it is accepted that, at the very least, globalisation has resulted in an increasingly common set of stimuli for national policy systems there is no guarantee that the stimuli will produce a uniform response. In other words, even if the 'reach' of global influence is similar the response may vary 
considerably. The variation in response might be due to the institutional constraints within national policy systems discussed above, but it might also be the result of the mechanisms through which international influence is manifest: the mechanisms may constitute independent variables in the shaping of domestic policy. This section examines a series of mechanisms which operate at the interface between the domestic and the international. The mechanisms are summarised in Table 2 along five dimensions which have been adapted from work by Dale (1999). While the Table fulfils a useful heuristic purpose it must be borne in mind that the different mechanisms are not, in practice, so neatly compartmentalised. As will be clear from the following discussion elements of some mechanisms can be found in others. Elements of path dependency may, for example, be identified in the empirical analysis of instances of policy learning and transfer.

The first dimension identifies in Table 2 concerns the locus of initiative for interaction between the international and the domestic. In some mechanisms, such as policy learning and policy transfer, the locus is clearly domestic as was the case in the UK when the then Minister, Ian Sproat, and senior civil servants visited the Australian Institute of Sport when the government was considering establishing a similar high performance training centre. In contrast the locus of initiative for the change in many domestic antidoping policies lay with the World Anti-Doping Agency (WADA), an international organisation. However, the mechanism which focuses on the possibility that policy determines or overrides politics is less easy to categorise as it is argued that the particular properties of a problem generate their own momentum towards certain policy choices creating, in effect, an 
institutional constraint on policy choice. The second dimension concerns the likely lead actor and varies between domestic government and/or interest groups and international transnational governmental or non-governmental policy regimes and emphasises the potential for agency in the relationship between the domestic and non-domestic policy spheres. However, as will be discussed in more detail below some theorists of policy change (Haas 1992, Hajer \& Wagenaar 2003, Fischer 2003) stress the capacity of ideas to constitute an independent variable in the policy process which has the potential to make the concept of a 'lead actor' redundant. The third dimension focuses attention on the basis of engagement between the international and domestic levels and the degree of constraint involved in policy choice and relates, as did the previous dimension, to debates about agency and institutionalism in policy decisions. The fourth dimension seeks to identify the key relationship, if any, that characterises the level of engagement. In many examples of policy transfer the relationship is bi-lateral as the initiation of the process of policy review is often domestic i.e. the acknowledgement of a problem. However, the intervention in domestic policy processes by international regimes is often the embodiment of a multi-lateral initiative. The final dimension is perhaps the most important and concerns the nature of power exercised or embodied in the relationship and is based loosely on Lukes' three 'faces' of power namely, the explicit exercise of power, the use of power to control or constrain the policy agenda, or power as ideology Lukes 2005). 
International policy regimes: state power or the power of ideas?

Krasner defines regimes as 'sets of implicit or explicit principles, norms, rules and decision-making procedures around which actors' expectations converge in a given area of international relations' (1983, p. 2). In attempting to operationalise this concept it is argued that successful regimes possess some or all of the following characteristics: first, they exhibit a degree of stability in the pattern of relationships between actors and, by implication possess some process by which voices/interests can be acknowledged or ignored; second, regimes possess the organisational capacity to fulfil maintenance functions, such as agenda setting, policy monitoring and review, verification of compliance and, in some, the enforcement of compliance; and third, regimes actively defend and promote their values. Many regimes therefore have an identifiable organisational capacity, such as a permanent secretariat, while others fulfil regime maintenance functions through the actions of one or more member states or organisations as, for example, does the United States in maintaining the regimes associated with the GATT agreement and nuclear non-proliferation. The organisational significance of the state may be balanced or replaced by that of non-governmental organisations such as the IOC and the international federations in relation to sport development regimes. It has also been suggested that direction and organisational capacity can be provided by an epistemic community which Haas has described as 'a network of professionals with recognised expertise and competence in a 
particular ... issue area' (1992, p. 3). Arguing that 'control over knowledge and information is an important dimension of power', Haas suggests that the potential of epistemic communities to exercise influence increases with uncertainty and particularly the uncertainty found in areas of policy where states are strongly dependent on the policy choices of other actors. Uncertainty and dependence are characteristics of aspects of elite development systems: there is, for example, considerable uncertainty about the most effective youth talent identification process and the optimal process for athlete development, and elite systems often operate in a complex pattern of interdependencies involving public, not-for profit and commercial organisations.

The most common explanation for the formation of regimes and the mechanisms by which they exert influence is that they are the creatures, if not the products, of hegemonic self-interest, where 'stronger states in the policy sector will dominate the weaker ones and determine the rules of the game' (Keohane \& Nye, p. 1977). It is possible to argue that the global anti-doping regime fits this analysis as the policy could be interpreted as seeking to eliminate 'cheap science' (i.e. doping) from sport thus allowing those countries with access to sophisticated and expensive science to exploit their advantage in order to maintain their place in the medal rankings.

An alternative, and less state-centred, explanation for the formation of regimes assumes that ideas matter first, in creating a predisposition to cooperate and comply, and second, in explaining the content of regime rules and how they evolve. According to Nadelmann, in his study of global prohibition regimes, 'moral and emotional factors related neither to political 
nor economic advantage but instead involving religious beliefs, humanitarian sentiments ... conscience, paternalism, fear, prejudice and the compulsion to proselytise can and do play important roles in the creation and the evolution of international regimes' (1990, p. 480). Checkel (see also Risse et al 1999) also emphasises the importance of ideas as a source of influence and argues that international institutions are often effective in shaping national policy due to a process of socialisation of key domestic policy actors in government such that 'sustained compliance [is] based on the internalisation of new norms' (2005, p. 804). Checkel argues that 'There is growing empirical evidence to suggest that what starts as strategic incentive-based cooperation within international institutions often leads at later points to preference shifts' (2005, p. 814).

Within elite sport two examples of regimes concern the Olympic Movement and anti-doping policy, and illustrate the interplay between organisational capacity and ideas. There are two ways in which one might regard the Olympic Movement as a policy regime: first, in relation to its promotion of Olympism as a value system and second, as the cluster of organisations that define the scope of elite sport outside the major commercial sports. Olympism, articulated in the Olympic Charter, expresses a clear set of principles and norms which should impact on the operation of National Olympic Committees, the preparation of athletes for Olympic competition, and the behaviour of athletes at the Olympic Games. While Olympism is undeniably vague and arguably increasingly symbolic, it has been an important point of reference for National Olympic Committees when framing bids to host the Games and has also been used as a justification for NOC decisions, for example the decision of the British Olympic Association not to 
select for the British team any athlete who has been found guilty of a serious doping violation. The regime values of the Olympic Movement are also promoted through a network of National Olympic Academies and the International Olympic Academy at Olympia. Perhaps a more persuasive example of an Olympic policy regime is the impact of the Olympic Movement on the definition of what constitutes elite sport. Not only does the Olympic Games increasingly shape the competition structure and elite athlete preparation timetable in many domestic systems but the inclusion or removal of a sport from the summer or winter Games has a clearly discernible impact on domestic government funding decisions. However, while the Olympic Movement actively seeks to promote Olympism and can therefore be accepted as an active, if not especially effective, regime the impact of the Olympic Movement on domestic conceptualisations of elite sport and what sports are valued is largely indirect as the sheer dominance of the Olympic Games is sufficient to affect policy in many countries. The exception might be in relation to the work of Olympic Solidarity which, through its development activities, does seek to promote the practice of the Olympic diet of sports and events.

An equally strong claim for regime status can be made in relation to antidoping centred on the activities of the World Anti-Doping Agency. Since its establishment in 1999 WADA, jointly governed by states and international sports organisations, has obtained agreement from all Olympic sports and endorsement from 192 governments. At the heart of WADA's activity is the World Anti-Doping Code which places a heavy emphasis on the values encapsulated in the phrase 'the spirit of sport' to justify its policy position. 
However, the Code is supported by a system of monitoring and a compliance structure and has been recently reinforced by UNESCO's preparation of an Anti-Doping Convention which imposes legal responsibilities on member countries. Demonstrating compliance with the World Anti-Doping Code and the UNESCO Convention has required many countries to revise their domestic anti-doping regulations and procedures.

Ascribing influence to international policy regimes is, however, rarely straightforward, as evidence of a high degree of actor compliance may only indicate an association rather than a causal relationship. Furthermore, there is considerable disagreement whether regimes as international institutions are more than simply a camouflage for state power. It is not just the theorists from the realist school of international relations, such as Strange (1983) that are sceptical about reducing the significance of the state, Keohane et al, for example, caution that 'states maintain control: the institutions themselves are quite weak' (1993, p. 17). Even if a strongly independent role is ascribing too much authority to regimes they may yet fulfil a secondary, but nonetheless important, aggregation or facilitation role on behalf of more substantial actors, such as states or possibly non-governmental organisations (NGOs) for example, the IOC in relation to anti-doping. But whether it is as independent or mediating variables there is a powerful accumulation of evidence that regimes have the capacity to affect policy in important areas of elite sport most notably in relation to anti-doping policy.

Policy learning, lesson-drawing and policy transfer 
Implicit in much of the discussion of the development of public policy at national level is the assumption that countries learn from each other and that a process of policy transfer is in operation. At a commonsense level policy learning and policy transfer are attractive. For example, the UK's main comparators in relation to elite sport success include France, Italy, Australia and Germany and it would be unrealistic and surprising not to expect UK policy-makers to find out what these countries do and at least ask the question whether their practices could be adapted to the UK context.

The cluster of related concepts of 'policy learning', 'lesson-drawing' and 'policy transfer' has featured prominently in much recent analysis of policy change. Policy-learning is rooted in an Eastonian systems model of the policy process where the policy-making cycle is regularly energised by feedback on the impact of existing policy. While the process of policy learning can therefore be largely domestic and insulated from experience in other countries or even other policy areas in the same country it is increasingly accepted that policy learning can and increasingly does involve analyses of similar policy areas and issues in other countries. More recent conceptualisations of policy learning have emphasised the intentional aspect of the process which moves beyond feedback on existing policy and involves the systematic scanning of the environment for policy ideas (see Yamamoto 2008) who notes that scanning is an integral part of elite development policy in Japan). Often this systematic scanning is undertaken as a routine activity by public officials and is a technical process rather than a political one. Extending DiMaggio and Powell's (1983) ideas about institutional isomorphism it may be argued that 
the greater the level of uncertainty involved in a public policy problem and the fewer the alternative policy responses, the more likely countries are to exhibit a form of mimetic isomorphism with regard to policy selection.

Hall (1986) provides a valuable typology of policy change identifying three levels or 'orders' of policy change which result, potentially at least, from policy-learning. First order changes are alterations to the intensity or scale of an existing policy instrument, an example of which in relation to funding would be the decision in March 2006 by the UK government to provide an additional $£ 200 m$ to help prepare athletes for the 2012 Olympic Games. Second order changes are those that introduce new policy instruments designed to achieve existing policy objectives: examples of which would include the many countries which have established dedicated elite sports training centres. Finally, third order changes are those that involve a change in policy goals of which the, short-lived, decision by the Canadian government in the 1990s to downgrade the pursuit of elite success would be an example (Green \& Houlihan, 2005).

Policy transfer refers to the process by which the lessons learnt (see Rose 2005 , for a fuller discussion of lesson-drawing) are transferred: how lessons are internalised, how lessons are recorded and described and how they are incorporated into a different organisational infrastructure and value system in the importing country or policy sector. Bearing in mind that policy can be variously conceptualised as aspiration, action (involving the commitment of resources) or inaction (Hogwood 1987, Jenkins 1978, Heclo 1972) Rose (2005, p. 16) defines policy transfer as 'action-oriented intentional activity'. An awareness of the extent to which the transfer mechanism 
facilitates or constrains transfer is crucial. For example, the important role of the armed forces in South Korea in developing elite athletes for the Olympic Games or the role of the high school and especially the university sectors in the United States in talent identification and development may be lessons that are clearly understood and learnt but which are difficult to transfer to a country such as the UK which does not have the institution of military conscription and where the cultural values of the higher education system preclude such a heavy emphasis on sporting success at the expense of educational attainment. As should be clear the analysis of the transfer process is as important as an understanding of the process of policy learning and lesson drawing. Lessons may well be accurately learned but be imperfectly transferred or transferred to an unsupportive organisational infrastructure or an unsympathetic value system.

The attractiveness of the concepts of policy-learning and transfer are not without problems, the most obvious of which are the difficulty of explaining how policy makers learn (Oliver 1997), what constitutes learning (Bennett and Howlett 1992) and how learning might be quantified (Pierson 1993). In addition there are substantial concerns relating to the process by which lessons are communicated and transferred policies are recreated in the receiving country (see Dolowitz and Marsh 1996, 2000). These concerns notwithstanding, it is clear that policy learning and transfer are well established practices within many governments and domestic policy areas including elite sport development.

\section{Path dependency}


Underlying much of the discussion about policy learning is the assumption that policy change will be affected by both past experience and new information. As Greener notes, policy learning 'considers policy legacies to be one of the most significant elements in determining present and future policy' (2002: 162). As such, policy learning has much in common with the concept of path dependency which suggests that initial policy decisions can determine future policy choices: that 'the trajectory of change up to a certain point constrains the trajectory after that point' (Kay, 2005, p. 553). Path dependency is also connected to the broader policy analysis literature on the importance of institutions which, for Thelen and Steinmo, are seen as significant constraints and mediating factors in politics, which 'leave their own imprint' (1992, p. 8). Whether the emphasis is on institutions as organisations or as sets of values and beliefs (culture) there is a strong historical dimension which emphasises the "relative autonomy of political institutions from the society in which they exist; $\ldots$ and the unique patterns of historical development and the constraints they impose on future choices" (Howlett \& Ramesh 1995, p. 27).

The relevance of institutionalism within sport policy analysis is clear. A number of authors have identified the organisational infrastructure of UK sport as a significant variable in shaping policy (Houlihan \& White 2002, Green \& Houlihan 2005, Pickup 1996,; Roche 1993, and Henry 2001). Krauss (1990) and Wilson (1994) drew similar conclusions with regard to the United States as did Macintosh (1991) and Macintosh \& Whitson (1990) in relation to Canada. Allocation of functional responsibility for sport, federalism, the use of 
'arms length' agencies, and the presence of a minister for sport are all seen as having a discernible impact on sport policy and its implementation. Similar claims for the significance of cultural institutions are also widespread. Beliefs, norms and values associated with social class (Birley 1996), gender (Hargreaves 1994), disability, (Thomas 2007), and ethnicity (Carrington \& Macdonald 2000) have all been demonstrated to have had, and indeed to continue to have, a marked impact on the character of UK sport policy.

Past decisions need to be seen as institutions in relation to current policy choices with path dependency capturing the insight that 'policy decisions accumulate over time; a process of accretion can occur in a policy area that restricts options for future policy-makers' (Kay 2005, p. 558). In a hard application of the concept of path dependency one would argue that early decisions in a policy area result in current policy being 'locked in' and also, perhaps, locked on to a particular policy trajectory. A softer application of the concept would suggest that early decisions do not lock a policy on a specific trajectory, but do constrain significantly subsequent policy options (Kay 2005). This softer version of path dependency would be compatible with the argument underpinning Esping-Andersen's regime typology and indeed with many other mechanisms discussed in this article. For example, the adoption of a policy designed to maximise Olympic medals has proved to be a slow and difficult process in some Scandinavian countries due to the cultural value of universalism of access to sport and the perception of Olympic elite sport as dis-engaged from everyday life (Augestad et al 2006). The pursuit of Olympic medals has been made more culturally palatable by arguing that the sporting 
elite is the product of an extensive policy of mass participation rather than the outcome of a system of scientific talent identification.

In summary, it may be hypothised that once a government takes the decision to value elite sport success (or to acknowledge the value given it in civil society) it is locked on to a predictable policy path usually involving the investment in specialist training facilities, cash payments to athletes, and the development of sport science capacity. While it is not impossible to 'devalue' elite sport success few countries have attempted to do so suggesting a prima facia case for further investigation of the path dependency hypothesis.

Does policy determines politics?

Extending and, to a degree, contrasting with the discussion in the previous section one of the most significant insights from some, often large $n$, comparative policy studies was that nationally distinct political characteristics were only very weakly correlated with particular policies and that the dominant developmental process in advanced industrial countries was one of convergence. Freeman (1985, p. 469) summarised the challenge as follows:

'The idea that distinctive and durable national policymaking styles are causally linked to the policies of states asserts that 'politics determines policy'. The policy sector approach argues, in contrast, that the nature of the problem is fundamentally connected to the kind of politics that emerges as well as the policy outcomes that result. The policy sector 
approach shifts our attention away from political inputs to categories of issues and outputs of the political system; it suggests that 'policy determines politics'.

In other words the intrinsic characteristics of the problem or issue 'will override whatever tendencies exist toward nationally specific policies' (Freeman 1985, p. 486). To quote Heinelt, "the thesis "policies determines politics" would imply - given that a policy sector [for example, elite sport] would be seen as the only relevant variable for explaining politics - that institutions, parties, forms of interest mediation, political culture etc. do not matter, only the policy sector does' (2005, p. 7).

One important, and possibly crucial, indicator of convergence in elite sports systems is the extent to which a broad range of countries with different political, socio-economic and cultural profiles adopt similar policy goals and instruments. As has already been suggested the proportion of, admittedly more wealthy, countries whose governments have accepted elite success as a sport policy goal is high and growing. If it is accepted that there is convergence in policy goals then the next area for investigation is in relation to the policy instruments that have been selected to achieve that goal and crucially whether the choice of policy instruments is constrained by the nature of the policy objective. In other words it can be hypothesised that there is little scope for variation in instrument selection if a country wants to win Olympic gold medals: either that some policy instruments are so much more effective than others that they are selected even though they may conflict with deeper cultural values or that the repertoire of policy instruments is so limited that 
there is little scope for variation in policy selection. The hypothesis that 'policy determines politics' is partially supported by the comparison of elite sport development systems in the volume edited by Houlihan and Green (2008). With the exception of the United States the other eight countries exhibited considerable similarity in their elite athlete development strategies despite having welfare traditions that ranged from social democratic (Norway) to neoliberal (New Zealand) and political systems that included the authoritarian (China) and the liberal-democratic (Australia). However, in order to move beyond observation to analysis it would be necessary to explore the policy process in much more detail particularly in relation to policy option evaluation and selection.

\section{Conclusion}

The theorising and empirical research around the issue of the mechanisms by which international and domestic policy systems interact in relation to elite sport is so scant and fragmented that it is tempting to use the academic's 'escape clause' of arguing that 'we need more empirical evidence'. In attempting to avoid such an anodyne conclusion (although we do need more empirical research) the following observations are offered.

First, it is important to bear in mind that the evidence of increasing similarity of elite sport systems across many economically developed countries does not necessarily indicate the activation and impact of some or indeed any of the mechanisms discussed above. It is possible, though I would 
argue improbable, that the similarity in elite systems is the consequences of individual domestic policy systems responding to an increasingly uniform global environment. According to this argument the extent to which a more homogenised policy agenda faced by countries is the result of globalisation is open to debate as it may simply be that shared problems and common socioeconomic developments such as the spillover of the use of sports drugs into wider society, declining family size resulting in the need for greater selectivity and precision in talent identification. As Whitty et al argued in relation to a study of policies designed to tackle inner city under-achievement in education, policy-makers in the UK and United States 'were working with similar frames of reference and producing parallel policy initiatives, rather than directly "borrowing" from one another' (1993, p. 14). While it is important to be cautious in claiming too significant a role in policy change for any of the mechanisms it also is important to acknowledge the growing body of research which indicates a steady blurring of the interface between the domestic and the international levels of the policy. On the one hand the evidence of policy learning and transfer among the richer countries is steadily accumulating particularly in relation to elite athlete development (Green and Oakley 2001a, 2001b, Houlihan and Green 2008); on the other hand there is evidence of effective international policy regimes becoming established most notably in relation to doping in elite sport (Yamamoto 2009), but also, at the European Union regional level, in relation to players conditions of employment. It is consequently arguable that there is a dual process in operation - a domestically initiated process of scanning the policy environment for transferable policies (an aspect of which would be compatibility with domestic 
culture) and an international process of regime development - which, when taken together contribute to a trend toward homogenisation of aspects of sport policy.

However, while regime analysis and policy transfer theory appear to be complementary there needs to be a degree of caution in combining different types of theoretical explanation. Although theoretical pluralism is not necessarily problematic there needs to be an awareness of the different types of theory that are being combined. Regime theory for example, is generally located within a neo-liberal interpretation of international politics and as such is an example of what Abend refers to as 'an overall perspective from which one sees and interprets the world' (2008, p. 179). This type of macro-level theory contrasts with theories of policy learning, policy transfer and isomorphism which are much more limited in explanatory ambition and are ‘explanation[s] of a particular social phenomenon' (Abend 2008, p. 178).

Following on from the first observation the second is that individual domestic policy systems are likely to be affected by more than one mechanism. It is plausible to hypothesise that at one level there are 'ideas in good currency' examples of which might include the nebulous notion of Olympism as well as more practical policies such as establishing specialist training centres for elite athletes. The latter example could be illustrative of the mechanism of mimetic isomorphism where change results less from external pressure and more from domestic policy uncertainty. It is also likely to be the case that many countries will be consciously (or perhaps subconsciously) involved in an accommodation with powerful international policy regimes and countries. The privileging, for funding purposes, of Olympic sports is likely to 
be a conscious acknowledgement of the dominance of the Olympic Games in the hierarchy of international sporting events. Conscious accommodations with the power distribution in sport is also likely to be evident in the particular sports that are prioritised within individual countries - for example avoiding those with established dominance by one or a few countries. Overlaying these two processes of interaction will be the more proactive engagement initiated by individual countries (policy learning and transfer) or by international policy regimes (designed to achieve harmonisation and compliance).

The third observation is to emphasise the importance of considering the power relations which each mechanism implies. In relation to policy learning and transfer it would appear that the power of initiative lay with the individual country as it was their decision to scan for alternative policy solutions. However, the strength of global policy discourses around issues such as elite success (and the extent to which it is considered a cipher for national vitality) and doping in sport (and the need to be seen to be active on the issue) may result in some countries feeling obliged to engage in policy learning and transfer because the cost (for example, damage to international prestige and risk of losing votes in the selection process to host major events) of being seen to do nothing would be too great.

In relation to international policy regimes it is important to bear in mind that their impact will be uneven as it is generally the weaker states whose domestic policy is more likely to be influenced. This is not only because the more powerful sporting countries are likely to have been instrumental in forming the regime or at least legitimising its actions, but also because the more powerful countries are more likely to have the resources to manage 
compliance in such a way as to minimise the disruption to current practice. Moreover, while the formation of global policy discourse can be a powerful constraint on domestic policy-making its existence does not necessarily imply, that policy necessarily becomes homogenised. Indeed there is strong evidence from studies in other policy areas which demonstrates the capacity of individual states to interpret and adapt external policy pressures to their particular national circumstances and history (Lundahl 2007, Taylor and Henry 2000, Ozga and Lingard 2007, Mares 2003, McEwen and Moreno 2005, Deacon 2000, Iversen 2005, Ellison 2006, Glatzer and Rueschmeyer 2005). Consequently, it is important to see the interface between nondomestic and domestic factors and the mechanisms that facilitate interaction as not only being about solving problems but about protecting and furthering interests whether of states or of international non-governmental organisations. 
Table 2: Mechanisms of international and domestic interaction

\begin{tabular}{|c|c|c|c|c|c|c|c|}
\hline Dimension & $\begin{array}{l}\text { Policy } \\
\text { learning }\end{array}$ & $\begin{array}{l}\text { Policy } \\
\text { transfer }\end{array}$ & $\begin{array}{l}\text { Path } \\
\text { dependency }\end{array}$ & $\begin{array}{l}\text { Mimetic } \\
\text { isomorphism }\end{array}$ & $\begin{array}{l}\text { Policy determines } \\
\text { politics }\end{array}$ & Harmonisation & Imposition \\
\hline $\begin{array}{l}\text { Locus of } \\
\text { initiative }\end{array}$ & National & National & $\begin{array}{l}\text { National/ } \\
\text { international }\end{array}$ & National & Intrinsic to policy & $\begin{array}{l}\text { International/ } \\
\text { national }\end{array}$ & International \\
\hline $\begin{array}{l}\text { Likely lead } \\
\text { actor/ } \\
\text { organisation }\end{array}$ & $\begin{array}{l}\text { Government/ } \\
\text { interest } \\
\text { groups }\end{array}$ & Government & Government & Government & Government & $\begin{array}{l}\text { International } \\
\text { Policy regime }\end{array}$ & $\begin{array}{l}\text { International } \\
\text { Policy regime }\end{array}$ \\
\hline $\begin{array}{l}\text { Basis of } \\
\text { engagement }\end{array}$ & Voluntary & Voluntary & Constrained & $\begin{array}{l}\text { Pressure to } \\
\text { conform }\end{array}$ & Constrained & $\begin{array}{l}\text { Voluntary or } \\
\text { compulsion }\end{array}$ & Compulsion \\
\hline $\begin{array}{l}\text { Key } \\
\text { relationships }\end{array}$ & Bi-lateral & Bi-lateral & None & Multi-lateral & None & $\begin{array}{l}\text { Multi-lateral/ } \\
\text { policy regime } \\
\text { lead agency }\end{array}$ & $\begin{array}{l}\text { Multi-lateral/ } \\
\text { policy regime } \\
\text { lead agency, but } \\
\text { can be bi-lateral }\end{array}$ \\
\hline $\begin{array}{l}\text { Nature of power } \\
\text { (explicit, } \\
\text { agenda setting, } \\
\text { ideological) }\end{array}$ & Explicit & Explicit & Agenda control & $\begin{array}{l}\text { Explicit/ } \\
\text { ideological }\end{array}$ & $\begin{array}{l}\text { Agenda control/ } \\
\text { ideological }\end{array}$ & $\begin{array}{l}\text { Explicit/ agenda } \\
\text { control/ } \\
\text { ideological }\end{array}$ & Explicit \\
\hline $\begin{array}{l}\text { Sport (UK) } \\
\text { Elite sport } \\
\text { development }\end{array}$ & $\begin{array}{l}\text { Pattern of } \\
\text { regular } \\
\text { contact } \\
\text { through } \\
\text { governments, } \\
\text { professional } \\
\text { organisations } \\
\& \text { academics }\end{array}$ & $\begin{array}{l}\text { Investment in } \\
\text { specialist } \\
\text { training } \\
\text { centres and in } \\
\text { sports } \\
\text { scientists }\end{array}$ & $\begin{array}{l}\text { Focus on elite } \\
\text { sport has led to a } \\
\text { separation of } \\
\text { elite sport policy } \\
\text { from policy on } \\
\text { mass } \\
\text { participation due } \\
\text { to power of elite } \\
\text { interests }\end{array}$ & $\begin{array}{l}\text { Adoption of } \\
\text { many policies } \\
\text { and } \\
\text { management } \\
\text { practices from } \\
\text { Australia, } \\
\text { former GDR } \\
\text { and Soviet } \\
\text { Union }\end{array}$ & $\begin{array}{l}\text { It is argued that once } \\
\text { the commitment to elite } \\
\text { sport success has been } \\
\text { made particular policies } \\
\text { are inevitably adopted } \\
\text { e.g. paying athletes, } \\
\text { specialist facilities, } \\
\text { investments in sport } \\
\text { science }\end{array}$ & $\begin{array}{l}\text { Doping control } \\
\text { through the } \\
\text { activities of the } \\
\text { World Anti- } \\
\text { Doping Agency }\end{array}$ & $\begin{array}{l}\text { Attempted } \\
\text { imposition of the } \\
\text { UN Convention } \\
\text { on the Rights of } \\
\text { the Child to } \\
\text { cover training of } \\
\text { young elite } \\
\text { athletes }\end{array}$ \\
\hline
\end{tabular}

Adapted from Dale 1999 


\section{References}

Abbott, A., Collins, D., Martindale, R. and Sowerby, K. 2002 Talent identification and development: An academic review. Edinburgh: Sport Scotland.

Abend, G. 2008 The meaning of "theory". Sociological Theory, 26(2), 173-199.

Amis, J. \& Cornwell, B. eds., 2005. Global sport sponsorship. Oxford: Berg. Andersen, S.S. and K.A. Eliassen, eds., 1993. Making policy in Europe: The Europeification of national policy-making. London: Sage.

Augestad, P., Bergsgard, N.A. \& Hansen, A.Ø., 2006 The institutionalisation of an elite sport organisation in Norway: the case of Olympiatoppen. Sociology of Sport Journal, 23(3), 293-313.

Bauman, Z., 1999 Globalization: the Human Consequences. Cambridge: Polity Press.

Bennett, C.J. \& Howlett, M., 1992. The lessons of learning: Reconciling theories of policy learning and policy change. Political Sciences ${ }_{2} 25$, $275-94$

Benson. J.K., 1982. Networks and policy sectors: A framework for extending inter-organisational analysis. In: Rogers, D. and Whitton, D., eds. Interorganisational co-ordination. Iowa: Iowa State University.

Birley, D., 1996. Playing the game: Sport and British society 1914-1945, Manchester: Manchester University Press.

Blomqvist, P., 2004. The choice revolution: privatization of Swedish welfare services in the 1990s. Social Policy and Administration, 38(2), 139-155. 
Carrington, B. \& Macdonald, I., 2000. 'Race', sport and British society. London: Routledge.

Cerny, P., 1995. Globalisation and the changing logic of collective action., International Organisation, 48, 595-625.

Checkel, J.T., 2005. International institutions and socialization in Europe: introduction and framework. International Organization, 59.(4), 801826.

Coleman, W. \& Perl, A., 1999. Internationalized policy environments and policy network analysis. Political Studies, 47(4), 691-709.

Dale, R., 1999. Specifying globalisation effects on national policy: A focus on the mechanisms, Journal of Education Policy, 14(1), 1-17.

David, P., 2005. Human rights in youth sport: A critical review of children's rights in competitive sports. London: Routledge.

Deacon, B. with M. Hulse and P. Stubbs 1997.. Global social Policy: International Organisations and the Future of Welfare. London: Sage.

Digel, H. 2002a Organisation of high performance athletics in selected countries (Final report for the International Athletic Foundation). Tübingen, Germany: University of Tübingen.

Digel, H. 2002. A comparison of competitive sports systems. New Studies in Athletics, 17(1), 37-49.

DiMaggio, P. \& Powell, W. 1983. The iron cage revisited: institutional isomorphism and collective rationality in organisational fields. American Sociological Review. 48, 147-160.

Dolowitz, D. \& Marsh, D., 2000. Learning from abroad: The role of policy transfer in contemporary policy making. Governance, 13, 5-24. 
Ellison, N., 2006. The transformation of welfare states? London: Routledge.

Esping-Andersen, G., 1990. The three worlds of welfare capitalism.

Cambridge: Polity Press.

Fischer, F., 2003. Reframing public policy: Discursive politics and deliberative practices. New York: Oxford University Press.

Fitch, R., 1996. The Assassination of New York. London: Verso.

Freeman, G.P., 1985. National styles and policy sectors: explaining structured variation. Journal of Public Policy, 5(4), 467-96.

Glatzer, M. \& Rueschmeyer, D., eds., 2005. Globalization and the future of the welfare state. Pittsburgh: University of Pittsburgh Press.

Green, M. \& Oakley, B., 2001a. Elite sport development systems and playing to win: uniformity and diversity in international approaches. Leisure Studies, 20(4), 247-267.

Green, M. \& Oakley, B., 2001b, Lesson drawing: International perspectives on elite sport development systems in established nations, Paper presented at the Nation and Sport conference. Brunel University, London, June.

Green, M. \& Houlihan, B., 2005. Elite sport development: policy learning and political priorities. London: Routledge.

Greener, I., 2002. Understanding NHS reform: The policy-transfer, social learning, and path dependency perspectives. Governance: An International Journal of Policy, Administration, and Institutions, 15(2), 161-183.

Haas, P. M., 1992. Introduction: epistemic communities and international policy co-ordination. International Organisation. 46, 1 - 35. 
Hall, P. A., 1986. Governing the economy: the politics of state intervention in Britain and France. Cambridge: Polity Press.

Hajer, M. and Wagenaar, H., eds., 2003. Deliberative policy analysis: Understanding governance in the network society. Cambridge: Cambridge University Press.

Hargreaves, J., 1994. Sporting females: critical issues in the history and sociology of women's sport. London: Routledge

Heclo, H., 1972. Review article, Policy analysis. British Journal of Political Science $_{2}$ II, 83-108.

Hechter, M., 1975. 'Review essay', Contemporary Sociology, 4, 217-22.

Henry, I., 2001. The politics of leisure policy, $2^{\text {nd }}$ edn. London: Palgrave.

Hirst, P. \& Thompson, G., 1999. Globalisation in question. $2^{\text {nd }}$ edn. Cambridge: Polity Press.

Hogwood, B., 1987. From crisis to complacency. Oxford: Oxford University Press.

Houlihan, B. and White, A. 2002. The politics of sport development: Development of sport or development through sport? London: Routledge.

Houlihan, B., 2007. Sport and globalization. In: B. Houlihan, ed. Sport and Society, $2^{\text {nd }}$. edn. London: Sage.

Houlihan, B. \& Green, M., eds., 2008. Comparative elite sport development: Systems, structures and public policy. Oxford: Butterworth-Heinemann. Howlett, R. \& Ramesh, M., 1995. Studying public policy: policy cycles and policy sub-systems. New York: Oxford University Press. Iversen, T., 2005. Capitalism, democracy and welfare. London: Routledge. 
Jenkins, W.I., 1978. Policy analysis: Political and organisational perspectives. London: Martin Robertson.

Kay, A., 2005. A critique of the use of path dependency in policy studies. Public Administration, 83(3), 553-571.

Keohane, R.O., Haas, P.M., \& Levy, M.A., 1993. The effectiveness of international environmental institutions. In: P.M. Haas, R.O. Keohane \& M.A. Levy, eds., Institutions for the earth: sources of effective international environmental protection. Cambridge, MA: The MIT Press.

Keohane, R.O., \& Nye, J., 1977.. Power and interdependence. Boston, MA: Little Brown.

Krasner, S., 1983. Structural causes and regime consequences: regimes as intervening variables. In: S. Krasner, ed., International regimes. Ithica, NY: Cornell University Press.

Krauss, R.G., 1990. Recreation and leisure in modern society, $4^{\text {th }}$ edn. New York: Harper Collins.

Leibfried, S., 1990. The classification of welfare state regimes in Europe, paper, Social Policy Association Annual Conference, University of Bath.

Lukes, S., 2005. Power: A Radical View. Basingstoke: Palgrave.

Lundahl, L., 2005. Swedish, European, global: The transformation of the Swedish welfare state. In: D. Coulby \& E. Zambeta, eds. World yearbook of education 2005: Globalisation and nationalism in education, London: Routledge Falmer.

Macintosh, D. \& Whitson, D., 1990. The Game Planners: Transforming Canada's sports system. Montreal: McGill-Queens University Press. 
Macintosh, D., 1991. Sport and the state: The case of Canada. In: F. Landry et al, eds. Sport ... The third millennium. Sainte-Foy: Les Presse de Universitairé de Laval.

Mares, I., 2003. The politics of social risk: business and welfare state development. Cambridge: Cambridge University Press.

McEwen, N. \& Moreno, L., eds., 2005. The territorial politics of welfare. London: Routledge.

Nadelmann, E.A., 1990. Global prohibition regimes: the evolution of norms in international society. International Organisation, 44(4), 479-526.

Oakley, B. \& Green, M., 2001. The production of Olympic champions: international perspectives on elite sport development systems. European Journal of Sport Management, 8 (Special Issue) 83-105.

Ozga, J. \& Lingard, B., 2007. Globalisation, education policy and politics. In: B. Lingard \& J. Ozga, eds. The Routledge Falmer reader in education policy and politics. London: Routledge.

Oliver, M.J., 1997. Whatever happened to monetarism? Aldershot: Ashgate.

Pickup, D., 1996. Not another messiah: An account of the Sports Council 1988-1993. Bishop Aukland: Pentland Press.

Pierson, P., 1993. When effect becomes cause: Policy feedback and policy change. World Politics, 45(4), 595-628.

Risse, T., Ropp, S. \& Sikkink, K., eds., 1999. The power of human rights: international norms and domestic change. Cambridge: Cambridge University Press. 
Roche, M., 1993. Sport and community: Rhetoric and reality in the development of British sport policy. In: J.C. Binfield and J. Stevenson eds., Sport, culture and politics. Sheffield: Sheffield Academic Press.

Rose, R., 2005. Learning from comparative public policy: a practical guide. London: Routledge.

Rosenberg, J., 2005. Globalization theory: A post mortem. International Politics. 42, 2-74.

Scholte, J.A., 2003. Globalisation: A critical introduction $2^{\text {nd }}$ edn. Basingstoke: Palgrave.

Siaroff, A., 1994. Work, women and gender equality: A new typology. In: D. Sainsbury, ed. Gendering welfare states, London: Sage.

Silk, M.L., Andrews, D.L. \& Cole, C.L., eds., 2005. Sport and corporate nationalism. Oxford: Berg.

Slack, T., ed., 2004. The commercialisation of sport. London: Routledge.

Strange, S., 1983.. Cave! hic dragones: a critique of regime analysis. In: S.D. Krasner, ed., International regimes. Ithica, NY: Cornell University Press.

Taylor, S. \& Henry, M., 2000. Globalisation and educational policymaking: A case study. Educational Theory. 50(4), 487-503.

Thelen, K. and Steinmo, S., 1992. Historical institutionalism in comparative politics. In: K. Thelen, S. Steinmo and F. Longstreth, eds., Structuring politics: Historical institutionalism in comparative analysis. Cambridge: Cambridge University Press.

Thomas, N., 2007. Sport and disability. In: B. Houlihan, ed., Sport and society: A student introduction, $2^{\text {nd }}$ edn. London: Sage. 
UK Sport, 2006. Sports policy factors leading to international sporting success: An international comparative study. London: UK Sport.

Whitty, G., Edwards, T. \& Gerwitz, S., 1993. Specialisation and choice in urban education. London: Routledge.

Wilson, J., 1994. Playing by the rules: Sport, society and the state. Detroit: Wayne State University Press.

Yamamoto, M.Y., 2008. Japan. In: B. Houlihanand M. Green eds. Comparative elite sport development: Systems, structures and public policy. Oxford: Butterworth-Heinemann.

Yamamoto, M.Y., 2009. The influence of international policy regimes on domestic sport policy (unpublished PhD thesis) Loughborough University, Loughborough. 